\title{
Citizen Science Driven Big Data Collection Requires Improved and Inclusive Societal Engagement
}

\author{
Oliver Dalby 1,2, Isadora Sinha',3, Richard K. F. Unsworth ${ }^{2,4}$, Len J. McKenzie ${ }^{5}$, \\ Benjamin L. Jones ${ }^{2,6}$ and Leanne C. Cullen-Unsworth ${ }^{2,3 *}$
}

${ }^{1}$ Centre for Integrative Ecology, School of Life and Environmental Sciences, Deakin University, Geelong, VIC, Australia, ${ }^{2}$ Project Seagrass, Bridgend, United Kingdom, ${ }^{3}$ Sustainable Places Research Institute, Cardiff, United Kingdom, ${ }^{4}$ College of Science, Swansea University, Swansea, United Kingdom, ${ }^{5}$ Centre for Tropical Water and Aquatic Ecosystem Research (TropWATER), James Cook University, Cairns, QLD, Australia, ${ }^{6}$ Department of Ecology, Environment and Plant Sciences, Stockholm University, Stockholm, Sweden

\section{OPEN ACCESS}

Edited by:

Jan J. C. Seys,

Flanders Marine Institute, Belgium

Reviewed by:

Michelle Jillian Devlin,

Centre for Environment, Fisheries and Aquaculture Science (CEFAS),

United Kingdom

Tymon Zielinski,

Institute of Oceanology (PAN), Poland

*Correspondence:

Leanne C. Cullen-Unsworth cullen-unsworth/c@cardiff.ac.uk; leanne@projectseagrass.org

Specialty section: This article was submitted to

Ocean Observation,

a section of the journal

Frontiers in Marine Science

Received: 25 September 2020 Accepted: 31 March 2021

Published: 07 May 2021

Citation:

Dalby O, Sinha I, Unsworth RKF,

McKenzie $L J$, Jones BL and Cullen-Unsworth LC (2021) Citizen Science Driven Big Data Collection Requires Improved and Inclusive Societal Engagement.

Front. Mar. Sci. 8:610397. doi: 10.3389/fmars.2021.610397
Marine ecosystems are in a state of crisis worldwide due to anthropogenic stressors, exacerbated by generally diminished ocean literacy. In other sectors, big data and technological advances are opening our horizons towards improved knowledge and understanding. In the marine environment the opportunities afforded by big data and new technologies are limited by a lack of available empirical data on habitats, species, and their ecology. This limits our ability to manage these systems due to poor understanding of the processes driving loss and recovery. For improved chances of achieving sustainable marine systems, detailed local data is required that can be connected regionally and globally. Citizen Science (CS) is a potential tool for monitoring and conserving marine ecosystems, particularly in the case of shallow nearshore habitats, however, limited understanding exists as to the effectiveness of CS programmes in engaging the general public or their capacity to collect marine big data. This study aims to understand and identify pathways for improved engagement of citizen scientists. We investigated the motivations and barriers to engagement of participants in CS using two major global seagrass CS programmes. Programme participants were primarily researchers in seagrass science or similar fields which speak to a more general problem of exclusivity across CS. Altruistic motivations were demonstrated, whilst deterrence was associated with poor project organisation and a lack of awareness of specified systems and associated CS projects. Knowledge of seagrass ecosystems from existing participants was high and gains because of participation consequently minimal. For marine CS projects to support big data, we need to expand and diversify their current user base. We suggest enhanced outreach to stakeholders using cooperatively identified ecological questions, for example situated within the context of maintaining local ecosystem services. Dissemination of information should be completed with a variety of media types and should stress the potential for knowledge transfer, novel social interactions, and stewardship of local environments. Although our research confirms the potential for CS to foster enhanced collection of big data for improved marine conservation and management, we illustrate the need to improve and expand approaches to user engagement to reach required data targets.

Keywords: citizen science, big marine data, seagrass monitoring, inclusivity, community engagement 


\section{INTRODUCTION}

In an age of biodiversity loss and increasing anthropogenic stressors, there is a need for robust monitoring to log and prevent further loss (Driscoll et al., 2018). Within the marine environment, coastal ecosystems provide considerable ecosystem services including blue carbon sequestration, sediment stabilisation, water filtration, and high primary productivity (Barbier et al., 2011). However, despite well-documented ecosystem services, coastal environments are undergoing extensive degradation (Worm et al., 2006; Halpern et al., 2008). Environmental disturbances associated with poor coastal and catchment management, coastal development, climate change, and invasive species act to impede the ecosystem functioning of these habitats worldwide (Worm et al., 2006; Halpern et al., 2008). The ramifications of this degradation are severe, both for ecology and society, and require considerable effort to quantify and monitor losses and/or shifts in biodiversity to better identify potential remedial management or restoration approaches (Diaz et al., 2006; Friedman et al., 2020). Achieving monitoring to this end requires coordinated, large workforces and the creation of Big Data on suitably fine spatial and temporal scales (Duffy et al., 2019; Friedman et al., 2020).

Big Data can be thought of as data sets that are so large, and collected so rapidly, that they become difficult to analyse/manage with traditional means. Often these datasets are required to have a number of the three $V$ 's; volume, the quantity of data collected, velocity, the speed at which the data is collected, and variety, the variation in the data set (Kitchin and McArdle, 2016). Within seagrass research, these $V$ 's can translate to (i) adequate spatial resolution and replication (likely requiring extensive intra-country sites across a large number of countries exhibiting seagrass ecosystems), (ii) adequate temporal resolution (seasonal or sub-seasonal sampling to capture both inter- and intra-annual variation), and (iii) adequate detail in collected data (ideally containing density and morphology, taxonomy, and reproductive biology). Collecting data that fit these requirements on a global scale each year is beyond the scope of traditional field researchers, especially given the high degree of heterogeneity and logistical challenges associated with working in marine environments, and require novel approaches to meet these goals (Liu et al., 2017).

Currently, the majority of long-term monitoring projects occur annually (Duffy et al., 2019), and likely do not occur at the required spatial resolution for coordinated global monitoring. Further, current estimates of seagrass distributions based on collations of existing data are incomplete, showing large variations in mapping effort and tools used between countries (McKenzie et al., 2020). As such, although numerous projects exist which collect data on seagrass ecosystems across a number of countries worldwide, these efforts cannot yet be considered truly global and coordinated.

Participation in citizen science (CS), defined as involvement of members of the public in scientific studies without a formal scientific background (Thiel et al., 2014), is rising globally (Ellwood et al., 2017). CS projects are used extensively in ecology (Kullenberg and Kasperowski, 2016), where increased workforces can dramatically increase data collection potential both spatially and temporally while potentially reducing funding requirements (Kobori et al., 2016). As such, CS projects can be an attractive option for ecological studies requiring the collection of Big Data where minimal or no additional training is required and may be a suitable method to remedy existing data gaps in global seagrass distributions and promote a coordinated global monitoring system with the intent of establishing continued, truly global, data collection (Duffy et al., 2019).

Seagrasses are an ecologically important, evolutionarily unique, and spatially declining coastal habitat known for their considerable ecosystem services (Unsworth et al., 2018; McKenzie et al., 2021). Seagrasses have, like other coastal marine ecosystems, undergone substantial declines worldwide with rates of loss estimated at 7\% per year (Waycott et al., 2009). Declines are linked to cumulative anthropogenic influences inducing reduced coastal water quality and accelerated habitat loss (Waycott et al., 2009; Short et al., 2011). Further, a lack of awareness of seagrass ecosystems in the general public leads to a lack of conservation effort and limited drive to reverse current losses (van Keulen et al., 2018). Potentially as a result of limited awareness and drive for conservation, seagrass CS projects exhibit limited participation and represent a small proportion of globally available CS projects (Jones et al., 2018).

Currently two seagrass CS projects exist which span large spatial scales and target considerable numbers of participants, namely Project Seagrass' SeagrassSpotter ${ }^{1}$ and Seagrass-Watch ${ }^{2}$. Growth of both projects has been considerable since their conceptions (Jones et al., 2018) (a brief overview of the number of participants of each project is located in the "Materials and Methods" section).

Despite the recent growth of seagrass science and associated CS projects (Hind-Ozan and Jones, 2018) minimal work has been completed on the current demographics, the degree of inclusivity, the motivations, and potential barriers to participation. Complexities of participation in CS projects from a sociological perspective include participant-specific drivers for initial, sustained, and discontinued participation (Geoghegan et al., 2016). Research into individual projects can aid and review project design, facilitating greater participation in conservation and better integration of the needs of stakeholders and citizen scientists (Cigliano et al., 2015). Concordantly, by better understanding trends in participation, CS projects can increase their ability to produce scientifically robust Big Data at spatio-temporal scales adequate to support marine monitoring and management.

This study investigates participation in the above outlined seagrass CS projects via an online questionnaire designed to gauge the ability of the projects to collect and facilitate the further collection of marine Big Data. Specifically, the following aspects were investigated: (1) demographics of users, (2) drivers of participation in relation to (i) existing literature and (ii) participant-specific responses, (3) perceived gains associated with participation, (4) barriers present in (i) entry-level approaches e.g., SeagrassSpotter (ii) traditional participatory approaches e.g.,

\footnotetext{
${ }^{1}$ www.seagrassspotter.org

${ }^{2}$ www.seagrasswatch.org
} 
Seagrass-Watch (iii) the use of mobile phones as monitoring tools, and (5) perceived knowledge gains via participation.

\section{MATERIALS AND METHODS}

A non-probability, convenience design was used to sample respondents (Etikan, 2016). Potential respondents were contacted via four seagrass orientated online groups (Table 1). Links to a questionnaire were included within contact media inviting the recipient to participate. Questionnaire creation and email dissemination processes were completed using Qualtrics software provided by the University of York. All responses were collected between 31/07/2018 and 5/09/2018. Any responses received after this date was not included in analyses.

Due to the non-probability approach taken throughout this study results herein are not representative of all CS volunteers (Van Selm and Jankowski, 2006). However, given that parties targeted for questionnaire dissemination were interested in seagrasses to some degree (Table 1), results can be considered representative of this group as a subpopulation (Etikan, 2016).

Ethical approval was obtained from the University of York Environment Department Ethics Committee. Informed consent to participate in the study was obtained from all participants prior to engagement in the questionnaire.

A conceptual framework of the questionnaire used throughout this study is contained in Supplementary Material 1. The questionnaire was comprised of five sections: Consent, SeagrassSpotter, Seagrass-Watch, Perceived Knowledge, and Demographic questions; utilised a range of question types: multiple choice, open ended, Likert-type and ranking exercises and was based on the design guidelines of Andrews et al. (2003).

\section{SeagrassSpotter and Seagrass-Watch}

SeagrassSpotter has accumulated around 3,050 sightings of 41 seagrass species from 95 countries or territories as of September 2020. Seagrass-Watch monitoring is established at 408 sites across 21 countries (Duffy et al., 2019). SeagrassSpotter and Seagrass-Watch each offer vastly different approaches to CS participation. Established in the United Kingdom in 2016, SeagrassSpotter presents an entry-level project utilising a primarily mobile interface; asking users to report sightings of seagrass via uploads of georeferenced photographs. Once submitted, additional information is supplied to accompany the uploaded photograph including phenology, associated fauna, and seagrass change (Jones et al., 2018). Conversely, Seagrass-Watch demonstrates a more traditional participatory approach, pairing citizen scientists with formally trained scientists to monitor trends in seagrass condition. Established in 1998 in Queensland (Australia), Seagrass-Watch has produced temporally long-term data which has proved a valuable tool for monitoring of established sites e.g., Great Barrier Reef, Queensland (McKenzie et al., 2012) and Singapore (McKenzie et al., 2017). To date, over 5,700 field site assessments have been conducted. Seagrass-Watch was founded as a community-based monitoring initiative but has evolved into the generally accepted methodology for seagrass monitoring utilised primarily by scientists; citizen scientists now contribute $40 \%$ of data when assisting scientists/environmental practitioners and $7 \%$ when operating without the supervision of a scientist (McKenzie et al., 2000, 2018).

Once consent was established, questionnaire respondents were asked if they were current users of SeagrassSpotter or participants of Seagrass-Watch. For respondents who answered "yes," length and frequency of participation was established. Motivations for participation and perceived benefits were then queried based on factors outlined in Geoghegan et al. (2016). Attitudes towards the use of mobile phones as monitoring tools were then gauged in addition to respondents ranking a series of deterring concepts identified by Geoghegan et al. (2016). Deterrence was further conceptualised by asking explicitly what respondents thought would deter someone from participation in the project. Respondents were then asked whether they understood how their contribution to SeagrassSpotter helped to conserve seagrass ecosystems. Following this, current participants in SeagrassWatch were questioned regarding their participation duration, frequency, motivations, and perceived barriers for that project specifically. Seagrass-Watch users were also asked whether they submitted their data to Seagrass-Watch HQ and to provide a reason if this was not the case. Respondents were then asked how they heard about the projects. Respondents who were not current users of a project were asked why this was the case and did not complete the respective project section.

\section{Perceived Knowledge}

Current users of either project were asked if they participated in additional CS projects, estimated their knowledge of seagrass ecosystems and their threats, and were asked to name threats to seagrasses in their area. Changes in perceived knowledge

TABLE 1 | Description and links to survey dissemination groups.

\begin{tabular}{|c|c|c|}
\hline Group name & Description & Link \\
\hline SeagrassSpotter Users & $\begin{array}{l}\text { Email list comprised of current registered users } \\
\text { of SeagrassSpotter }\end{array}$ & NA \\
\hline Seagrass-Watch Users & $\begin{array}{l}\text { Email list comprised of current registered users } \\
\text { of Seagrass-Watch }\end{array}$ & NA \\
\hline Murdoch University Seagrass Email Forum & $\begin{array}{l}\text { Email forum comprised of people interested in } \\
\text { seagrass ecosystems }\end{array}$ & http://lists.murdoch.edu.au/mailman/listinfo/seagrass_forum \\
\hline United Kingdom Seagrass Network & $\begin{array}{l}\text { Facebook group comprised of people } \\
\text { interested in seagrass ecosystems - } \\
\text { United Kingdom based }\end{array}$ & https://www.facebook.com/groups/545617545497309/ \\
\hline
\end{tabular}


throughout participation within the respective projects were then gauged. Interaction with the marine environment and the nature of interaction with seagrasses were established to identify primary user groups.

\section{Demographics}

All participants were asked to answer additional optional questions regarding their demography, education, and profession.

\section{Data Analysis}

Analyses were completed within Qualtrics survey design software (Qualtrics, 2018) and R 3.5.0 (R Core Team, 2013) using the "psych" (Revelle, 2017) and "ggplot2" packages (Wickham and Chang, 2016). Participant responses were coded and summarised using simple frequencies and percentages. Where questions were open ended, responses underwent deductive content analysis (Hsieh and Shannon, 2005) to identify major themes. Concepts identified in the literature were used to create a categorisation matrix on which codes were based to reduce subjectivity (Elo and Kyngäs, 2008; Saunders et al., 2014; Supplementary Material 2).

Values from ranking and Likert-type scales were treated as interval data throughout analyses (Carifio and Perla, 2008). Thus, it was assumed that neighbouring items demonstrated an equal change in participant response regardless of position e.g., 1-2 on a scale was the same change as 4-5 (Sullivan and Artino, 2013). Perceived motivations and barriers to participation were summarised as frequencies per rank e.g., the number of times a concept was scored within each rank (1-10). Knowledge scores were summarised using means and standard deviations.

Cronbach's alpha was calculated as a measure of reliability for Likert-type scales investigating deterrence and knowledge (Cronbach, 1951). Alpha values were not calculated for questions ranking motivations as the survey design allowed participants to only choose concepts which applied, giving rise to incomplete data rows. Alpha coefficients suggested scales could be considered reliable as values were above accepted thresholds (SeagrassSpotter deterrence $=0.82$ range $0.73-0.91$, SeagrassWatch deterrence $=0.88$ range $0.79-0.96$, knowledge $=0.94$ range $0.9-0.97$; all $>0.7$ ). It should be noted that thresholds are guidelines and are application-specific (Lance et al., 2006) and that Cronbach's alpha values calculated here may be subject to inflation due to disproportionate increases in the number of covariates with an increasing number of scales analysed (Agbo, 2010). Further, Cronbach's alpha is not a measure of dimensionality (Trizano-Hermosilla and Alvarado, 2016). Multidimensionality was not assessed due to small sample sizes compared to those needed for robust assessment (Costello and Osborne, 2005) and should be expected here due to sociological complexities of concepts analysed (Jordan et al., 2011; Martin V. Y. et al., 2016). Influences of multidimensionality on conclusions drawn are, however, likely to be minimal given the study assessed multidimensional concepts influencing seagrass CS users, as opposed to attempting to identify unidimensional factors constituting each concept.

Comparisons of project participation, demographics, and perceptions of mobile devices were tested using Fisher's exact tests due to small observed values (Crawley, 2013). Within each project, perceived knowledge scores were correlated against participation duration and frequency using Spearman rank correlation coefficients (Murray, 2013) and were tested between demographics using Mann-Whitney $U$ tests.

\section{RESULTS}

\section{Demographics}

Throughout the sample period, the questionnaire was completed 65 times; one respondent did not consent, thus valid $n=64$. Respondents demonstrated similar demographics between SeagrassSpotter and Seagrass-Watch. Both projects demonstrated a variety of ages and countries of residence skewed toward the geographic origins of projects (Table 2). Gender of users was lightly skewed towards greater female participation (Table 2).

Samples of both projects were dominated by users who held undergraduate or postgraduate degrees (SeagrassSpotter: 90.9\%, Seagrass-Watch: 87.5\%). Degree levels varied between projects, with SeagrassSpotter users demonstrating a greater proportion of doctoral degrees (Table 2). Users primarily aligned their employment with educational and research professions, with the latter constituting an overwhelming proportion of current SeagrassSpotter users (80.5\%). Around half of all respondents $(48.4 \%)$ stated that their profession was directly involved with seagrass ecosystems. An almost equal proportion (47.5\%) stated that their employment was affiliated with a university or equivalent organisation. Research was also a primary reason for interaction with seagrass ecosystems, although this was of lessened importance in Seagrass-Watch which showed a similar proportion of citizen scientists (Table 2). Generally, country of residence did not differ from the country in which users worked with seagrasses (73.3\%).

Respondents demonstrated a loosely equal likelihood of participating in additional CS projects to those investigated (SeagrassSpotter: 40.9\%, Seagrass-Watch: 50\%, median number of additional projects $=2$ ). Users of either project discovered the opportunity via social media, websites, and word of mouth (Table 2). Beach walking, SCUBA diving, monitoring, snorkelling, and other watersports comprised respondent's primary methods of interaction with the marine environment (Table 3).

\section{Participation Length and Frequency}

Current SeagrassSpotter users constituted a greater number of respondents than those of Seagrass-Watch, both projects, and non-users (Table 4); this variation was not significant statistically (Fisher's exact test $p>0.05$ ). Length and frequency of participation also differed between projects (Table 4). Users of SeagrassSpotter reported short to medium (1-18 months) participation lengths whilst participation in Seagrass-Watch was comprised of longer durations ( $>5$ years). Participation frequency was heavily skewed towards infrequent (once every few months) and incidental use in SeagrassSpotter, whilst SeagrassWatch users demonstrated infrequent but regular or annual participation (Table 4). 
TABLE 2 | Demographics of users of current SeagrassSpotter and Seagrass-Watch users summarised as frequency and valid percent (brackets).

\begin{tabular}{|c|c|c|c|}
\hline & & SeagrassSpotter & Seagrass-watch \\
\hline \multirow[t]{9}{*}{ Age } & Under 18 & $0(0)$ & $0(0)$ \\
\hline & $18-24$ & $1(4.6)$ & $0(0)$ \\
\hline & $25-34$ & $8(36.4)$ & $2(28.6)$ \\
\hline & $35-44$ & $4(18.2)$ & $1(14.3)$ \\
\hline & $45-54$ & $4(18.2)$ & $1(14.3)$ \\
\hline & $55-64$ & $2(9.1)$ & $0(0)$ \\
\hline & $65-74$ & $2(9.1)$ & $2(28.6)$ \\
\hline & $75-84$ & $1(4.6)$ & $1(14.3)$ \\
\hline & 85 or older & $0(0)$ & $0(0)$ \\
\hline \multirow[t]{2}{*}{ Gender* $^{\star}$} & Male & $10(45.5)$ & $3(42.9)$ \\
\hline & Female & $12(54.6)$ & $4(57.1)$ \\
\hline \multirow[t]{7}{*}{ Education } & Less than high school degree & $0(0)$ & $0(0)$ \\
\hline & High school graduate & $0(0)$ & $0(0)$ \\
\hline & College but no degree & $2(9.1)$ & $1(12.5)$ \\
\hline & Bachelor's degree & 7 (31.8) & $4(50)$ \\
\hline & Master's degree & $2(9.1)$ & $1(12.5)$ \\
\hline & Doctoral degree & $11(50)$ & $2(25)$ \\
\hline & Professional degree & $0(0)$ & $0(0)$ \\
\hline \multirow[t]{7}{*}{ Employment* } & Professional or technical & $1(4.8)$ & $1(16.7)$ \\
\hline & Educational & $2(9.5)$ & 2 (33.3) \\
\hline & Retail trade & $1(4.8)$ & $0(0)$ \\
\hline & Accommodation or food & $1(4.8)$ & $0(0)$ \\
\hline & Arts, entertainment, recreation & $1(4.8)$ & $0(0)$ \\
\hline & Researcher/scientist & $15(71.4)$ & $2(33.3)$ \\
\hline & Unclassified & $0(0)$ & $1(16.7)$ \\
\hline \multirow[t]{5}{*}{ Involvement with seagrasses } & Research (Academic/University) & $11(50)$ & $1(12.5)$ \\
\hline & Research (NGO or equivalent) & $2(9.1)$ & $3(37.5)$ \\
\hline & Government work & $1(4.6)$ & $0(0)$ \\
\hline & Citizen Scientists & $4(18.2)$ & $3(37.5)$ \\
\hline & Other: student, teacher, interested party & $4(18.2)$ & $1(12.5)$ \\
\hline \multirow[t]{5}{*}{ How did you hear about the project? } & Word of mouth & $6(27.3)$ & $3(37.5)$ \\
\hline & Online & $4(18.2)$ & $1(12.5)$ \\
\hline & Social media & $7(31.8)$ & $0(0)$ \\
\hline & Print media & $0(0)$ & $1(12.5)$ \\
\hline & Other: profession, conference, volunteer group & $5(22.7)$ & $3(37.5)$ \\
\hline \multirow[t]{14}{*}{ Country of residence* } & Australia & $7(24.1)$ & $7(43.7)$ \\
\hline & Finland & $2(6.9)$ & $1(6.25)$ \\
\hline & Germany & $1(3.4)$ & $1(6.25)$ \\
\hline & Greece & $1(3.4)$ & $0(0)$ \\
\hline & Japan & $2(6.9)$ & $1(6.25)$ \\
\hline & Netherlands & $1(3.4)$ & $0(0)$ \\
\hline & Philippines & $1(3.4)$ & $2(12.5)$ \\
\hline & South Africa & $1(3.4)$ & $0(0)$ \\
\hline & Sri Lanka & $1(3.4)$ & $0(0)$ \\
\hline & Timor-Leste & 1 (3.4) & $1(6.25)$ \\
\hline & Thailand & $0(0)$ & $1(6.25)$ \\
\hline & United Kingdom & $8(27.6)$ & $1(6.25)$ \\
\hline & United States & $3(10.3)$ & $0(0)$ \\
\hline & Vanuatu & $0(0)$ & $1(6.25)$ \\
\hline
\end{tabular}

${ }^{*}$ Results shown represent options with tallied responses only.

The majority of Seagrass-Watch users submitted their data to Seagrass-Watch HQ (Table 5). Reasons for non-submission included taking part as a larger organisation or group, utilising adapted Seagrass-Watch methods but not taking part in SeagrassWatch surveys specifically, and data compatibility or submission issues (Table 5). 
TABLE 3 | Respondent's primary methods of interaction with the marine environment.

\begin{tabular}{lc}
\hline Code & Frequency and valid percent \\
\hline Beach Walking & $20(24.1)$ \\
SCUBA Diving & $12(14.5)$ \\
Monitoring or surveys & $12(14.5)$ \\
Snorkelling & $11(13.3)$ \\
Watersports (sailing, kayaking etc.) & $11(13.3)$ \\
Swimming & $8(9.6)$ \\
Fishing & $4(4.8)$ \\
Beach cleans & $1(1.2)$ \\
Other: cycling, comments on the & $4(4.8)$ \\
frequency of interaction & \\
\hline
\end{tabular}

\section{Motivations, Benefits, and Barriers to Participation}

Motivations for participation were similar between seagrass CS projects although the relative importance of each concept differed (Figure 1). SeagrassSpotter users were primarily driven by contributing to scientific knowledge, helping wildlife (both in general and area-specific contexts), and by sharing their knowledge with others. Lesser motivations included learning something new or developing new skills (Figure 1). SeagrassWatch users, however, were primarily motivated by meeting people and taking part for fun, in addition to influences of contributing to scientific knowledge and helping wildlife. Seagrass-Watch users also attributed further motivation to progressing their careers, because another person wanted them to, to spend time outdoors, to learn something new, and as a form of exercise (Figure 1).

Respondents did not perceive that their motivations had changed over time (Table 6) citing considerable previous monitoring of seagrasses, and a view that their actions can protect the environment more generally as contributing factors. Respondents that reported a change cited development within the project, attending conferences, and involving the local community as drivers of change.

Respondents reported a range of benefits associated with participation in SeagrassSpotter including increases in knowledge, a sense of contribution to science and the environment more generally and sharing knowledge with other users. Secondary benefits included using SeagrassSpotter as a record of sightings, developing social connections, spending time outdoors, and learning new skills (Table 6).

As with motivations for participation, deterring concepts were similar between projects (Figure 1). Respondents highlighted poor feedback, communication, disorganisation, a lack of impact or output, personal circumstances and underappreciation as deterring concepts. Seagrass-Watch users stated formal training and funding issues as additional project-specific barriers and generally reported higher deterrence scores than SeagrassSpotter users (Figure 1).

Non-users of seagrass CS projects reported similar deterring concepts to current participants (Table 7), citing personal circumstance as the primary driver of non-participation. Nonusers of both projects highlighted a lack of awareness of the opportunity to participate, in addition to project-specific concepts of not downloading the SeagrassSpotter app and a

TABLE 4 | Variation in the number of participants, participation length and frequency of focal seagrass citizen science projects.

\begin{tabular}{|c|c|c|c|c|}
\hline & & \multicolumn{3}{|c|}{ Do you currently take part in SeagrassSpotter? } \\
\hline \multirow{2}{*}{ Do you currently take part in Seagrass-Watch? } & No & 22 & \multicolumn{2}{|c|}{25} \\
\hline & \multicolumn{2}{|c|}{ SeagrassSpotter } & \multicolumn{2}{|c|}{ Seagrass-watch } \\
\hline \multirow{4}{*}{ Length $^{\dagger}$} & 9-12 months & $6(20)$ & $1-2$ years & $1(6.3)$ \\
\hline & 13-18 months & $3(10)$ & $3-4$ years & $2(12.5)$ \\
\hline & Greater than 18 months & $2(6.7)$ & Greater than 5 years & $8(50)$ \\
\hline & Can't remember & $4(13.3)$ & Can't remember & $2(12.5)$ \\
\hline \multirow[t]{6}{*}{ Frequency ${ }^{\dagger}$} & More than once a week & $0(0)$ & More than once a week & $0(0)$ \\
\hline & Once every few months & $8(26.7)$ & Once every few months & $4(25)$ \\
\hline & Incidentally & $17(56.7)$ & Quarterly & $4(25)$ \\
\hline & Once a year & $3(10)$ & Once a year & $2(12.5)$ \\
\hline & Less often & $0(0)$ & Less often & $2(12.5)$ \\
\hline & Not sure & 1 (3.3) & Not sure & $2(12.5)$ \\
\hline
\end{tabular}

\footnotetext{
${ }^{\dagger}$ Time periods are specific to either project based on the period they have been available and participation style.
} 


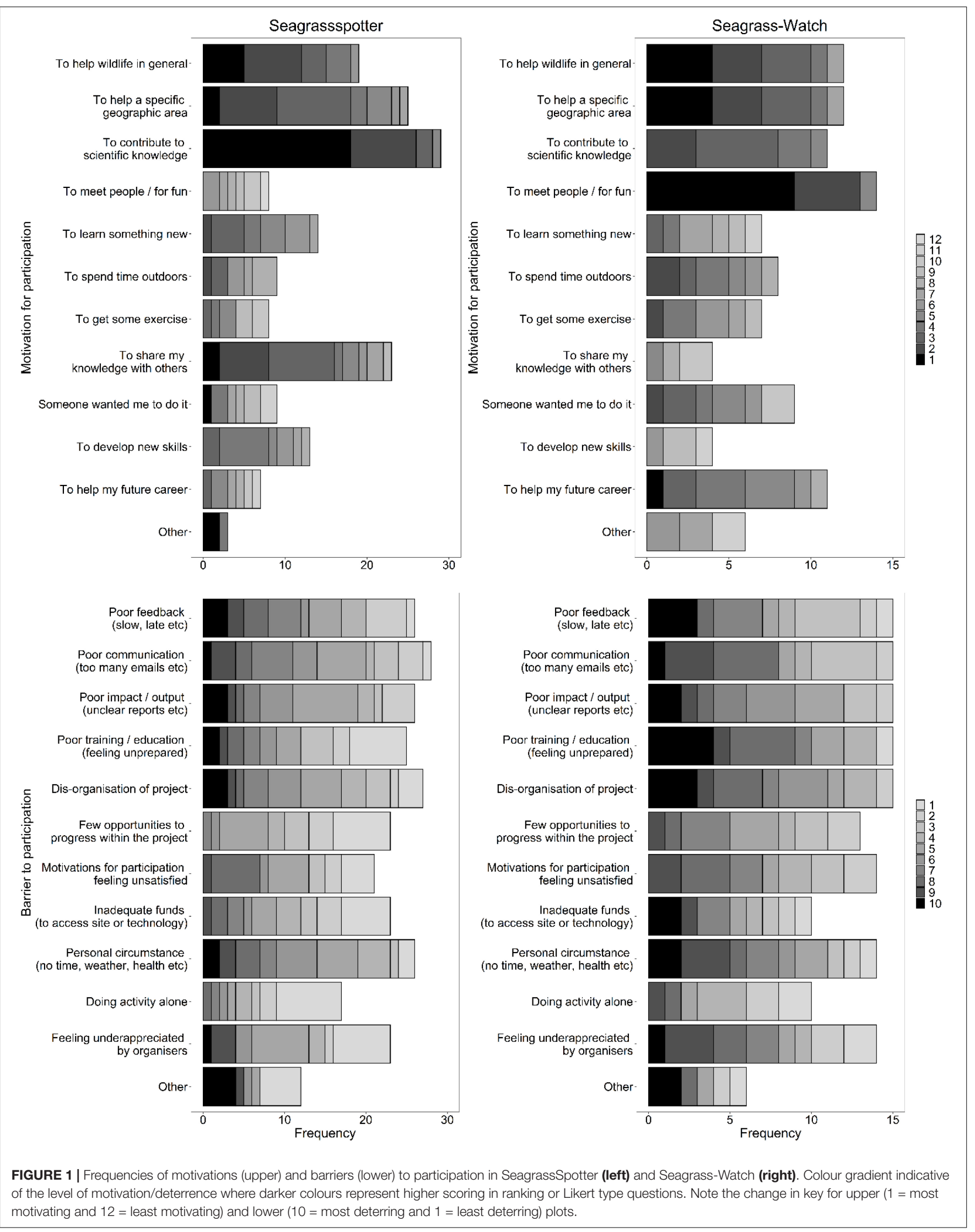


TABLE 5 | Proportion of Seagrass-Watch users who submit their data to Seagrass-Watch HQ and reasons for non-submission.

\begin{tabular}{|c|c|c|c|}
\hline \multicolumn{4}{|c|}{ Data submitted to Seagrass-watch HQ? } \\
\hline \multirow[t]{2}{*}{ Frequency and valid percent } & & Yes & No \\
\hline & & $9(60)$ & $6(40)$ \\
\hline \multirow[t]{7}{*}{ Reason for non-submission } & Code & Frequency and valid percent & Example comment \\
\hline & Organisation submits the data & $2(28.6)$ & "Not me personally, but my organisation does" \\
\hline & Methods have been simplified & $1(14.3)$ & $\begin{array}{l}\text { "... we use the Seagrass-Watch method as a } \\
\text { basis but have simplified it for use with local } \\
\text { volunteers" }\end{array}$ \\
\hline & $\begin{array}{l}\text { Unsure whether the } \\
\text { organisation submits the data }\end{array}$ & $1(14.3)$ & $\begin{array}{l}\text { "(data) goes to our local seagrass survey } \\
\text { organisers, and we aren't sure if they are still } \\
\text { organised to do anything with it" }\end{array}$ \\
\hline & Data not compatible & $1(14.3)$ & $\begin{array}{l}\text { "Our data is not compatible to the system in } \\
\text { Queensland" }\end{array}$ \\
\hline & Participated as a group & $1(14.3)$ & "Took part in the survey as part of a group" \\
\hline & Did not take part fully & $1(14.3)$ & "I have not really taken part in Seagrass-Watch" \\
\hline
\end{tabular}

lack of availability of Seagrass-Watch programmes local to them (Table 7).

\section{Technology and Mobile Phones}

SeagrassSpotter users demonstrated positivity towards mobile phones as conservation tools (Table 8), attitudes were not influenced by participant age or country of residence (Fisher's exact test, $p>0.05$ ).

When asked what would deter them from continued participation, SeagrassSpotter users cited an overly complex design, lack of interest, poor mobile reception/Wi-Fi, nervousness over submitting incorrect data and a perceived lack of impact as primary factors (Table 8). Concerns were also raised by two respondents regarding security and use of participant personal data. Concerns over mobile reception/Wi-Fi were also raised by respondents when barriers to the use of mobile phones were gauged specifically. Concerns regarding a lack of access and level of comfort when using mobile devices were also raised. Despite this, most respondents perceived no additional barriers via mobile phone utilisation, instead citing ease of access, technological benefits and the potential for wide geographical spread as supporting their implementation (Table 8).

\section{Perceived Knowledge of Seagrass Ecosystems}

Generally, respondents reported considerable knowledge of seagrass ecosystems and their threats, mean knowledge of seagrass: 8.09 ( \pm 2.18$), 7.63( \pm 1.77), 7.13( \pm 2.23)$, mean knowledge of threats: $8.41( \pm 1.56), 7.38( \pm 1.85), 7.25( \pm 2.12)$ for participants of SeagrassSpotter, Seagrass-Watch, and both projects respectively. Perceived knowledge scores did not differ significantly with the project users participated in (Mann-Whitney $U$ test, $p>0.05$ ). When the nature of interaction with seagrasses was analysed within a project-specific context (Figure 2), only SeagrassSpotter users demonstrated a significant change (Mann-Whitney $U$ test, Knowledge of seagrass: $p=0.006, \mathrm{df}=4, X^{2}=14.37$, Knowledge of threats: $p=0.008, \mathrm{df}=4, X^{2}=13.81$ ), other projects did not produce significant results (Mann-Whitney $U$ test, $p>0.05$ ). Users who interacted with seagrasses as part of academic research or government work reported higher scores than citizen scientists and those with "other" interactions. Scores reported by nongovernmental organisation researchers fluctuated considerably between projects (Figure 2). When gauged, perceived changes in knowledge throughout participation varied substantially between projects (Table 9). Reasons for perceived changes were similar between projects with respondents citing knowledge increases concerning training and methodologies, ecology behind observed trends, and knowledge gained from attending events (Table 9). Location-specific knowledge, greater environmental intervention, and wider ecological knowledge were cited as additional gains in SeagrassSpotter and Seagrass-Watch, respectively (Table 9). Perceived knowledge scores did not correlate with project-specific participation and frequency (Spearman's rank correlation, $p>0.05$ throughout).

SeagrassSpotter users stated that they knew how their contribution helped to conserve seagrass ecosystems (Table 10). Perceived roles of contributions discussed increasing data coverage of seagrasses, references to data being used as preliminary work for more complex studies, and increasing awareness of seagrass ecosystems generally (Table 10).

Seagrass CS users identified a range of threats to seagrass ecosystems (Table 11). Salient themes throughout responses included references to physical damage, coastal development, changes to water quality, and climate change (Table 11).

\section{DISCUSSION}

Citizen science has been highlighted as a potential tool for improving the collection of Big Data in marine science through wide involvement of the general public, particularly in poorly mapped and poorly understood ecosystems such as seagrass meadows. Here we demonstrate that in the case of seagrass systems, the use of CS, although assisting with management and conservation, is largely ineffective at collecting 
TABLE 6 | Perceived changes in motivations and benefits to participation in seagrass citizen science projects.

\begin{tabular}{|c|c|c|c|c|c|}
\hline \multicolumn{2}{|c|}{ Do you think your motivations have changed over the period of participation? } & \multicolumn{2}{|l|}{ SeagrassSpotter } & \multicolumn{2}{|c|}{ Seagrass-watch } \\
\hline & & Yes & No & Yes & No \\
\hline & & $3(10)$ & $27(90)$ & $3(18.6)$ & $13(81.3)$ \\
\hline Reason behind response & Code & $\begin{array}{l}\text { Frequency and } \\
\text { valid percent }\end{array}$ & Exampl & omment & \\
\hline Seagrass Spotter Perceived change & Involved the local community & $1(10)$ & $\begin{array}{l}\text { "Althoug } \\
\text { getting o } \\
\text { and it er } \\
\text { involved }\end{array}$ & $\begin{array}{l}\text { started a } \\
\text { oup of lo } \\
\text { m up bein } \\
\text { marine cc }\end{array}$ & $\begin{array}{l}\text { git for work, I ended up } \\
\text { kids to do it with me } \\
\text { a great way to get them } \\
\text { servation" }\end{array}$ \\
\hline \multirow[t]{3}{*}{ No perceived change } & Long term monitoring/prior work & $6(60)$ & $\begin{array}{l}\text { "I work v } \\
\text { and afte }\end{array}$ & seagras & $\begin{array}{l}\text { and other algae before } \\
\text { assSpotter" }\end{array}$ \\
\hline & Protect the environment & $2(20)$ & $\begin{array}{l}\text { "I still be } \\
\text { environn }\end{array}$ & $\begin{array}{l}\text { e the pro } \\
\text { t" }\end{array}$ & t can help protect the \\
\hline & Other: stated no change & $1(10)$ & & & \\
\hline \multirow[t]{2}{*}{ Seagrass-Watch Perceived change } & Progression within the project & $1(16.7)$ & $\begin{array}{l}\text { "At the } k \\
\text { have be } \\
\text { am [a] C } \\
\text { so / am }\end{array}$ & $\begin{array}{l}\text { inning I } w \\
\text { part of th } \\
\text { dinator. } \\
y \text { motivat }\end{array}$ & $\begin{array}{l}\text { a new volunteer, now I } \\
\text { rogram since } 1998 \text { and } \\
\text { have a } 20 \text {-year dataset, } \\
\text { to keep it going." }\end{array}$ \\
\hline & Attend conferences & $1(16.7)$ & $\begin{array}{l}\text { "I am no } \\
\text { regularly } \\
\text { conferer }\end{array}$ & $\begin{array}{l}\text { Dassionat } \\
\text { tend inter } \\
\text { s" }\end{array}$ & $\begin{array}{l}\text { or seagrass in W.A. and } \\
\text { tional seagrass }\end{array}$ \\
\hline \multirow[t]{3}{*}{ No perceived change } & Long term monitoring & 2 (33.3) & $\begin{array}{l}\text { "I have } k \\
\text { project, } \\
\text { now" }\end{array}$ & $\begin{array}{l}\text { monitor } \\
\text { one area }\end{array}$ & $\begin{array}{l}g \text { as part of a long-term } \\
\text { r) more than } 9 \text { years }\end{array}$ \\
\hline & Prior research involvement & $1(16.7)$ & $\begin{array}{l}\text { "l am do } \\
\text { seagras }\end{array}$ & $\begin{array}{l}\text { research } \\
\text { are unde }\end{array}$ & $\begin{array}{l}\text { seagrass before and } \\
\text { ppreciated in research" }\end{array}$ \\
\hline & Other: stated no change & $1(16.7)$ & & & \\
\hline \multirow[t]{7}{*}{ Benefits of participation ${ }^{\dagger}$} & Knowledge increase & $13(35.2)$ & $\begin{array}{l}\text { "I suppo } \\
\text { about ec } \\
\text { world in } \\
\text { this topi } \\
\text { the situa }\end{array}$ & $\begin{array}{l}\text { anything } t \\
\text { ystems, } t \\
\text { neral. The } \\
\text { he more I } \\
\text { n..." }\end{array}$ & $\begin{array}{l}\text { tinvolves education } \\
\text { environment and [the] } \\
\text { nore I understand about } \\
\text { n do things to change }\end{array}$ \\
\hline & Contribution to science & $9(24.3)$ & $\begin{array}{l}\text { "Feeling } \\
\text { environn }\end{array}$ & $\begin{array}{l}\text { at I contrik } \\
\text { tt..." }\end{array}$ & to to science and the \\
\hline & Sharing knowledge & $7(18.9)$ & $\begin{array}{l}\text { "I can st } \\
\text { profit fro } \\
\text { gatherec }\end{array}$ & $\begin{array}{l}\text { e my know } \\
\text { the know }\end{array}$ & $\begin{array}{l}\text { dge with others and also } \\
\text { ge others have already }\end{array}$ \\
\hline & Record of sightings & $3(8.1)$ & $\begin{array}{l}\text { "Get to } \\
\text { access" }\end{array}$ & e a recor & f my sightings that I can \\
\hline & Social Connections & $2(5.4)$ & $\begin{array}{l}\text { "Seagra } \\
\text { network }\end{array}$ & $\begin{array}{l}\text { Spotter pr } \\
\text { people w }\end{array}$ & $\begin{array}{l}\text { ides a connection with a } \\
\text { king my field of research" }\end{array}$ \\
\hline & Spend time outdoors & $2(5.4)$ & $\begin{array}{l}\text { "Looking } \\
\text { other sit }\end{array}$ & $\begin{array}{l}\text { tour curre } \\
\text { where we }\end{array}$ & $\begin{array}{l}\text { sites and venturing into } \\
\text { ink seagrass may be" }\end{array}$ \\
\hline & Learning new skills & $1(2.7)$ & $\begin{array}{l}\text { "...learn } \\
\text { different }\end{array}$ & $\begin{array}{l}\text { concept } \\
\text { vironmen }\end{array}$ & $\begin{array}{l}\text { learning more about a } \\
\text { nd how to protect it" }\end{array}$ \\
\hline
\end{tabular}

${ }^{\dagger}$ Current Seagrass-Watch users were not asked how they thought they benefited from participation.

Big Data as it is not currently reaching out effectively to the wider population, nor is it engaging the general public in understanding an underappreciated and largely unknown ecosystem. As a result of this limited outreach, seagrass CS projects in their current form fall short of the spatial and temporal resolutions and work forces required to globally monitor and manage this important ecosystem. Results outlined provide valuable insight into participation and knowledge transfer in SeagrassSpotter and Seagrass-Watch and represent the first known attempt to quantify such concepts in a seagrassspecific context.

\section{Demographics and Participation}

Countries that participated in seagrass CS projects were concordant with the variation in marine CS projects worldwide, with enhanced uptake in Europe, Australia, and United States Thiel et al. (2014). Increased participation in the United Kingdom and Australia is likely due to increased awareness of SeagrassSpotter and Seagrass-Watch in their home countries. Participating countries are also concordant with previous work summarising the demographics of existing seagrass research groups (Hind-Ozan and Jones, 2018). Similarly, users of both projects primarily cited "research" as a rationale 
TABLE 7 | Perceived barriers to participation in seagrass citizen science projects from non-users.

\begin{tabular}{|c|c|c|c|}
\hline Barriers to participation & Code & Frequency and valid percent & Example comment \\
\hline \multirow[t]{4}{*}{ SeagrassSpotter Non-users } & Personal circumstance & $13(39.4)$ & $\begin{array}{l}\text { "not finding the time" "relocation to a } \\
\text { part of the country that is inland" }\end{array}$ \\
\hline & Lack of awareness & $10(30.3)$ & $\begin{array}{l}\text { "Didn't realise it was a thing before this } \\
\text { questionnaire" }\end{array}$ \\
\hline & $\begin{array}{l}\text { Do not have the app } \\
\text { downloaded }\end{array}$ & $4(12.1)$ & "Have not yet installed the app..." \\
\hline & $\begin{array}{l}\text { Other: lack of ID skills, species } \\
\text { not available on the app }\end{array}$ & $6(18.2)$ & \\
\hline \multirow[t]{4}{*}{ Seagrass-Watch Non-users } & Personal circumstance & $24(47.1)$ & $\begin{array}{l}\text { "I had no available time to lately, but I } \\
\text { want to do more" }\end{array}$ \\
\hline & Lack of awareness & $15(29.4)$ & "I've never heard of it" \\
\hline & Lack of programme availability & $8(16.7)$ & $\begin{array}{l}\text { "None organised locally, and no time to } \\
\text { organise one myself" }\end{array}$ \\
\hline & Other: respondent unsure & $4(7.8)$ & \\
\hline
\end{tabular}

for interaction with seagrass ecosystems and participation in seagrass CS generally (Table 2). Increased participation, both in terms of geographic location and profession, was thus associated with users who were already aware of these projects through their professions. Within these user groups, length and frequency of participation was concordant with the length of time the project had been available (Jones et al., 2018) and how the project was designed, either incidental (SeagrassSpotter) or structured (Seagrass-Watch) (McKenzie et al., 2001).

\section{Motivation and Deterrence}

Users of both projects cited altruistic and environmentally positive concepts, knowledge development and social interactions as motivations and benefits of participation (Table 6). Altruism is frequent within environmental CS and indicates a drive to protect the environment for the good of others (Schwartz et al., 2012) and can be achieved via personal actions and by contributing to science, which is viewed as beneficial (Martin V. et al., 2016). Motivation by attainment and sharing of knowledge is also common (Rotman et al., 2014), with increased knowledge associated with an increase in environmentally positive behaviours (Bela et al., 2016). Minimal changes in motivations throughout participation (Table 6), also support the idea that users are altruistically involved with seagrass CS projects. Users who identified changes in motivations cited themes that implied a degree of environmental stewardship and project responsibility, whether by raising awareness via discussions or by ensuring the project's longevity through facilitating further recruitment.

Concordance was shown in deterring concepts, notably, inadequate communication and feedback, and a lack of demonstrable impact (Figure 1). Such deterrence likely results from perceptions that participants' time is not adequately validated for continued participation (Bruyere and Rappe, 2007) and may lead to feelings of underappreciation within users (Geoghegan et al., 2016). Project-specific barriers also arose via differing project approaches. Lessened influence of personal circumstance in SeagrassSpotter was likely due to reduced temporal investment, whilst prominent deterrence via a lack of sufficient formal training and available funds in Seagrass-Watch reflected greater task complexity, logistical, and financial investments associated with taking part (Franzoni and Sauermann, 2014). A lack of awareness of the existence of seagrass CS projects was also a significant barrier to participation (Table 7). Minimal public awareness of seagrass ecosystems is a known threat to their conservation and management (van Keulen et al., 2018) and results here suggest that little progress has been made to alleviate this thus far.

\section{Perceived Knowledge of Seagrass Ecosystems}

Users of both projects reported high knowledge scores. This is unsurprising given that researchers are likely to perceive increased levels of academic knowledge (Raymond et al., 2010). Variation in scores with the nature of interaction with seagrass ecosystems (Figure 2) is also unsurprising as traditional citizen scientists, those with minimal academic background in the subject, may have less academic knowledge of seagrass ecosystems compared to a researcher in that field. Citizen scientists may, however, hold considerable traditional ecological knowledge if they exist in close association with the oceans e.g., fishers (Drew, 2005) but may report modest scores due to the complexities of assessing knowledge (Raymond et al., 2010). Limited knowledge development reported by SeagrassSpotter users (Table 9) is likely influenced by researcher dominated demographics and an associated saturation of seagrass specific knowledge in this user group. Similarly, greater reported knowledge development in Seagrass-Watch may have been due to a higher proportion of citizen scientists, and thus greater potential for the attainment of novel information.

\section{Mobile Technologies}

SeagrassSpotter users demonstrated substantial support for the use of mobile phones as CS tools (Table 8), citing benefits that is concordant with the wider literature (Brammer et al., 2016). Despite respondent's positivity towards mobile devices, barriers to utilisation remained. Overly complex designs and requiring 
TABLE 8 | Perceptions of mobile phones as data collection tools by current SeagrassSpotter users.

\begin{tabular}{|c|c|c|c|c|}
\hline \multicolumn{2}{|c|}{$\begin{array}{l}\text { Do you think mobile phones are an } \\
\text { effective data collection tool for citizen } \\
\text { science? }\end{array}$} & \multicolumn{3}{|c|}{ Do you think mobile phones will create further barriers to participation? } \\
\hline Yes & No & & Yes & No \\
\hline $26(86.7)$ & $4(13.3)$ & & $9(30)$ & $21(70)$ \\
\hline Reason for choice & Code & Frequency and valid percent & Examp & e comment \\
\hline \multirow[t]{8}{*}{ Deterring concept ${ }^{\dagger}$} & Overly complex design & $6(20)$ & $\begin{array}{l}\text { "if it wa } \\
\text { user-fri }\end{array}$ & $\begin{array}{l}\text { overly complicated or not very } \\
\text { ndly" }\end{array}$ \\
\hline & Lack of interest & $4(13.3)$ & "... sol & eone not interested in seagrass" \\
\hline & Poor mobile/Wi-Fi reception & $3(10)$ & $\begin{array}{l}\text { "If the } \\
\text { interne }\end{array}$ & $\begin{array}{l}\text { op does not work in low quality network, or if it requires an } \\
\text { connection at all times..." }\end{array}$ \\
\hline & $\begin{array}{l}\text { Nervous about wrong species } \\
\text { ID }\end{array}$ & $3(10)$ & "Confic & nce in identification of seagrass" \\
\hline & Perceived lack of impact & $3(10)$ & $\begin{array}{l}\text { "If Sea } \\
\text { toward }\end{array}$ & $\begin{array}{l}\text { ass Spotter users didn't see their entries/data being used } \\
\text { some greater purpose" }\end{array}$ \\
\hline & Challenging environment & $2(6.7)$ & $\begin{array}{l}\text { "..mu } \\
\text { [being] }\end{array}$ & $\begin{array}{l}\text { unknown terrain, dangerous unseen objects. Discomfort } \\
\text { irty" }\end{array}$ \\
\hline & Data security & $2(6.7)$ & "If user & data is compromised or used inappropriately" \\
\hline & $\begin{array}{l}\text { Other: language, access to } \\
\text { device, environmental impact of } \\
\text { survey, unnecessary use }\end{array}$ & $7(23.3)$ & & \\
\hline \multirow[t]{3}{*}{ Effective tool } & Ease of access & $12(52.2)$ & $\begin{array}{l}\text { ". . pec } \\
\text { with th } \\
\text { easier. }\end{array}$ & $\begin{array}{l}\text { le use their mobile phones more and more and carry them } \\
n \text { on a frequent basis it makes the uploading of sightings } \\
\text { " }\end{array}$ \\
\hline & Technological benefits & $4(17.4)$ & "Mobile & $\begin{array}{l}\text { phones often used to photograph and record... torch can } \\
\text { les be handy" }\end{array}$ \\
\hline & Wide data spread & $3(13)$ & "Wide & ach and return of greater data spread" \\
\hline \multirow[t]{2}{*}{ Not an effective tool } & Various aspects affect use & $3(13)$ & $\begin{array}{l}\text { "Ipartic } \\
\text { situatio }\end{array}$ & ation] depends on volunteers, climate, geographic \\
\hline & Other: general comment & $1(4.4)$ & $\begin{array}{l}\text { "I think } \\
\text { can be }\end{array}$ & $\begin{array}{l}\text { hone apps are useful tools. However, I think many others } \\
\text { Iseful to" }\end{array}$ \\
\hline \multirow[t]{5}{*}{ Perceived barriers } & No barriers & $11(55)$ & "I think & hones are the future. They are very user friendly" \\
\hline & $\begin{array}{l}\text { Limits use to people with } \\
\text { access }\end{array}$ & $3(15)$ & "...col & $\begin{array}{l}\text { dexclude some people in developing nations or poorer } \\
\text { here smartphone use is not widespread" }\end{array}$ \\
\hline & Limits use to those comfortable & $3(15)$ & $\begin{array}{l}\text { "[The] } \\
\text { to mob }\end{array}$ & $\begin{array}{l}\text { oject is limited to responses from people that have access } \\
\text { e phone and would feel confident using the application" }\end{array}$ \\
\hline & Reception/Wi-Fi coverage & $2(10)$ & $\begin{array}{l}\text { ". app } \\
\text { for tho }\end{array}$ & $\begin{array}{l}\text { that don't require internet to run are the most accessible } \\
\text { working in remote locations" }\end{array}$ \\
\hline & Other: respondent unsure & $1(5)$ & & \\
\hline
\end{tabular}

†Current Seagrass-Watch users were not asked specifically what would deter them from further participation.

reception/Wi-Fi were cited both here (Table 8) and in previous assessments [e.g., Newman et al. (2011)], even when the project allowed for data submission at a later date e.g., SeagrassSpotter. Access to mobile devices and level of user comfort were also cited as barriers here (Table 8), however, a lack of influence of age and country of residence on perceptions suggested that these concepts may not influence participation in SeagrassSpotter. Further, "inadequate funds" was a minor deterrence in SeagrassSpotter users (Figure 1) suggesting access to seagrass sites (and associated travel costs) and/or mobile devices were not major barriers to participation.

Concerns over data security and correct identification of species were also raised by respondents (Table 8). Data handling and security present future challenges for mobile CS projects dealing with "Big Data" and should be considered a priority for future development (August et al., 2015). Despite data validation techniques being utilised in both SeagrassSpotter and SeagrassWatch, users were still concerned about submitting erroneous reports (Table 8). We suggest that these features are more widely advertised to users to prevent the development of an avoidable barrier to participation (Martin V. Y. et al., 2016).

\section{Participant Classification and Implications for the Future}

Following the categorisations of Danielsen et al. (2014), the results of our questionnaire indicate that seagrass CS projects examined currently lie primarily in type $\mathrm{E}$ (monitoring and executed by scientists) with minor involvement of citizen scientists. The researcher heavy demographic shown here can likely be considered a result of both a lack of awareness of seagrass ecosystems and their associated CS projects within the general 


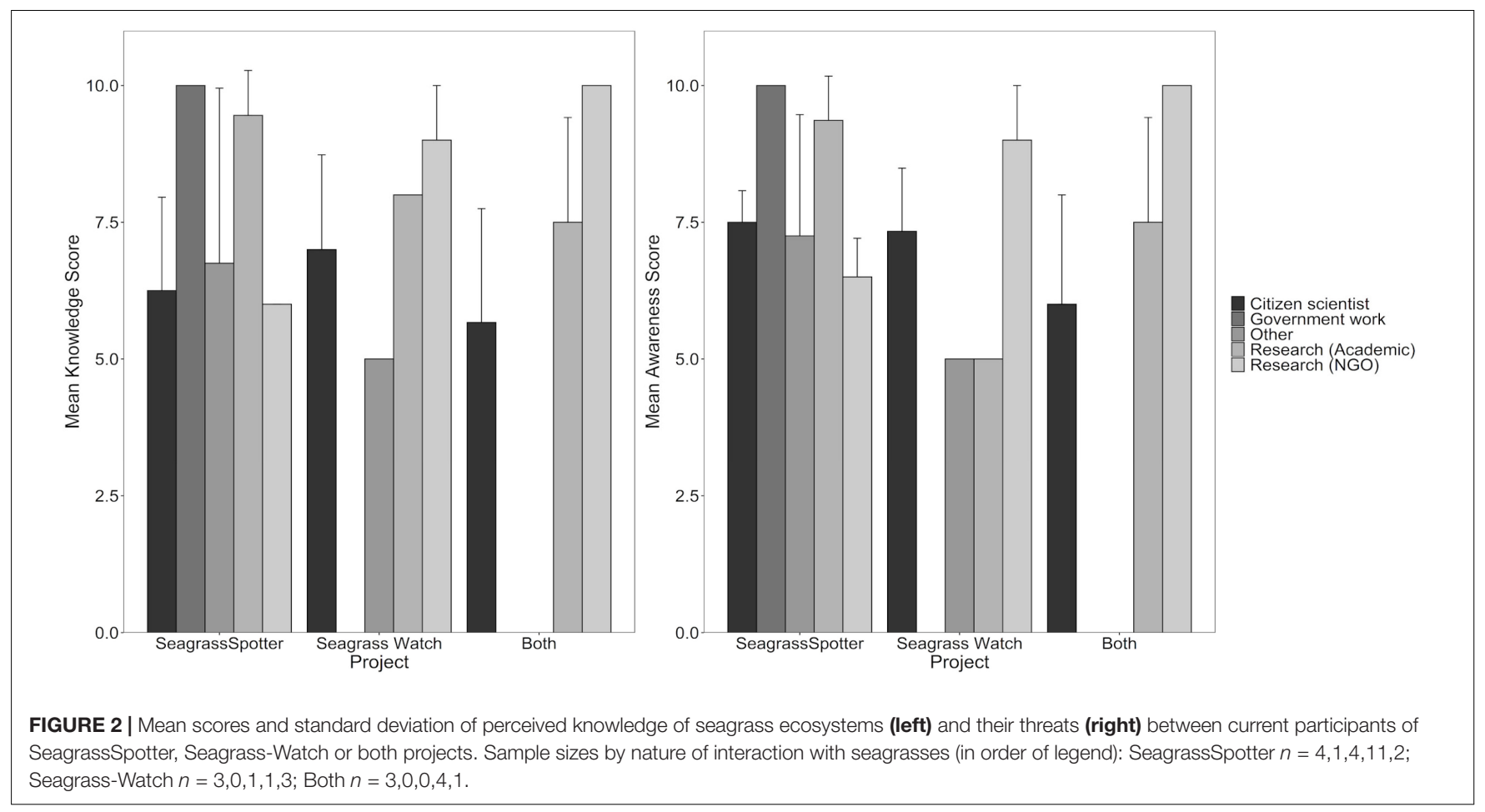

public and a lack of engagement with true citizen scientists and their communities.

It is evident that seagrass CS projects need to diversify their user bases if these projects are to be viable as long term monitoring schemes. Exclusivity in projects demonstrated here also prevents these organisations from building the participant networks required to collect marine Big Data. Specifically, seagrass CS projects are suffering from reduced potential to build a diverse user base that is logistically capable of collecting data on the spatio-temporal scales needed to monitor or manage marine environmental change. For seagrass CS projects to become capable of building large, diverse user bases there is a need for better community integration. Collaborative research projects between scientists and local communities that aim to answer mutually important questions (e.g., bottom-up project creation) are far more likely to succeed due to better alignment of the interests of scientists with those of stakeholders and/or community groups (Bradshaw, 2003; Conrad and Daoust, 2008). Alignment of these interests can lead to increased motivation for participation within the local community, which gives rise to a more inclusive, and often larger, user group (Geoghegan et al., 2016); and as a result, a greater potential for Big Data collection (Figure 3).

Greater inclusivity in seagrass CS projects, if facilitated, may also produce secondary benefits to the project and associated communities (Figure 3). By enhancing the development of social capital by integrating the project (and associated researchers) into local communities, larger communication networks can be produced (Jordan et al., 2012). These networks will likely demonstrate a shared identity (e.g., people interested in conserving the marine environment) in addition to shared values, norms, and trust between parties (Pretty and Smith, 2004) and may reduce community marginalisation by facilitating social interactions with groups who would otherwise not interact (Conrad and Hilchey, 2011). Once communication networks begin to expand, so will awareness of the seagrass CS project and seagrass ecosystems more generally, leading to increased participation, a greater potential for knowledge transfer, and reductions in scientific illiteracy. Participation in seagrass CS projects may also warrant benefits for individual participants via the facilitation of positive interactions with nature. These interactions can pose substantial benefits to the individual [e.g., stress reduction, restoration of attention, and improved psychological wellbeing (Keniger et al., 2013)] and when combined with community-orientated changes above may lead to heightened chances of environmentally positive actions, localised environmental management and stewardship, and greater willingness to bring environmental issues to the knowledge of policymakers (Haywood, 2014; Hyder et al., 2015; Hausmann et al., 2016).

Diversification of seagrass CS projects towards greater community inclusivity may not require an overhaul of existing methodologies or the creation of new projects. Instead, existing easily understandable CS projects can be used to help local communities answer ecological questions of interest (e.g., geographic arrangement of seagrass meadows and influences on fisheries catch). It is critical that if seagrass CS projects are to be integrated in this manner that research questions are identified from a bottom-up co-research approach and that both academics and community partners are treated equally. There is increasing interest in how new technologies can become integrated into CS programmes in order to 
TABLE 9 | Perceived gains in knowledge of seagrass ecosystems via participation in seagrass citizen science.

\begin{tabular}{|c|c|c|c|}
\hline & & SeagrassSpotter & Seagrass-watch \\
\hline \multirow{2}{*}{$\begin{array}{l}\text { Do you think your knowledge of } \\
\text { seagrass ecosystems has changed } \\
\text { whilst taking part in SeagrassSpotter or } \\
\text { Seagrass-Watch? }\end{array}$} & Yes & $16(53.3)$ & $15(93.8)$ \\
\hline & No & $14(46.7)$ & $1(6.3)$ \\
\hline Reason for choice & Code & $\begin{array}{l}\text { Frequency and } \\
\text { valid percent }\end{array}$ & Example Comment \\
\hline \multirow[t]{5}{*}{ SeagrassSpotter Perceived change } & Location-specific knowledge & $4(28.6)$ & $\begin{array}{l}\text { "I have learned more about the species found } \\
\text { on my island, and their distribution" }\end{array}$ \\
\hline & Training and methods & $2(14.3)$ & "Experience and training" \\
\hline & $\begin{array}{l}\text { Ecology behind observed } \\
\text { trends }\end{array}$ & $1(7.1)$ & $\begin{array}{l}\text { "Discussing observation and working out } \\
\text { reasons for change" }\end{array}$ \\
\hline & $\begin{array}{l}\text { Greater environmental } \\
\text { intervention }\end{array}$ & $1(7.1)$ & "Stopped local potting inside a small area" \\
\hline & Attended events & $1(7.1)$ & $\begin{array}{l}\text { "I have attended several workshops and gained } \\
\text { new insight" }\end{array}$ \\
\hline \multirow[t]{2}{*}{ No perceived change } & $\begin{array}{l}\text { Considerable previous } \\
\text { knowledge }\end{array}$ & $4(28.6)$ & $\begin{array}{l}\text { "... When using Seagrass Spotter I was } \\
\text { searching for seagrass as part of my own } \\
\text { research" }\end{array}$ \\
\hline & Lack of time for participation & $1(7.1)$ & $\begin{array}{l}\text { "I have been too busy this year to put any time } \\
\text { or focus into increasing my skills and } \\
\text { knowledge" }\end{array}$ \\
\hline \multirow[t]{4}{*}{ Seagrass-Watch Perceived change } & Attended events & $2(28.6)$ & $\begin{array}{l}\text { "I have learned a lot of new information through } \\
\text { Seagrass-Watch training and subsequent } \\
\text { monitoring events" }\end{array}$ \\
\hline & Training and methodologies & $2(28.6)$ & $\begin{array}{l}\text { "... learned about the techniques (transects, } \\
\text { quadrats and soil corer, epiphytes etc.,..." }\end{array}$ \\
\hline & Wider ecological knowledge & $2(28.6)$ & $\begin{array}{l}\text { ". . finding out about blue carbon [and], the } \\
\text { habitats of various marine life that need } \\
\text { seagrass to survive" }\end{array}$ \\
\hline & $\begin{array}{l}\text { Ecology behind observed } \\
\text { trends }\end{array}$ & $1(14.3)$ & $\begin{array}{l}\text { "Over a period of years [I] have seen some } \\
\text { interesting trends in the data" }\end{array}$ \\
\hline
\end{tabular}

TABLE 10 | Perceptions of how contributing to SeagrassSpotter helps to conserve seagrass ecosystems.

\begin{tabular}{|c|c|c|c|}
\hline \multicolumn{4}{|c|}{$\begin{array}{l}\text { Do you understand how your contribution to SeagrassSpotter } \\
\text { helps conserve seagrass ecosystems? }\end{array}$} \\
\hline & Yes & & No \\
\hline \multirow[t]{4}{*}{ Perceived role of contribution } & Code & Frequency and valid percent & Example comment \\
\hline & Increasing data coverage & $15(68.2)$ & $\begin{array}{l}\text { ". . .bring more knowledge of the occurrence of } \\
\text { different seagrass species from certain areas } \\
\text { and so promote the importance of biodiversity } \\
\text { in seagrass meadows" }\end{array}$ \\
\hline & Acts as groundwork & $4(18.2)$ & "It may help with basic groundwork..." \\
\hline & Increasing awareness & $3(13.6)$ & $\begin{array}{l}\text { "Both increasing awareness and increasing } \\
\text { coverage [of] data" }\end{array}$ \\
\hline
\end{tabular}

maximise their effectiveness and expand the use of the results that are collected (McClure et al., 2020). Artificial intelligence is a particular avenue of expanding interest in CS and numerous speculative potential benefits proposed (McClure et al., 2020). Given the clear gaps in the reach of these seagrass CS programmes to wider society and particular marginalised social groups, AI could be used to align the marketing of such programmes to different groups using social media.

Further, while many CS projects rely upon the goodwill of genuinely interested members of the public, finding ways of increasing this pool of participants is necessary to increase the impact of CS. An approach to diversify participation in seagrass CS would be for conservationists and scientists to build 
TABLE 11 | Perceived threats to seagrass ecosystems by current users of seagrass citizen science projects.

\begin{tabular}{lc}
\hline Perceived threat & $\begin{array}{c}\text { Frequency and } \\
\text { valid percent }\end{array}$ \\
\hline Physical damage & $12(14)$ \\
Coastal development & $12(14)$ \\
Water quality & $10(11.6)$ \\
Climate change & $9(10.5)$ \\
Pollution & $8(9.3)$ \\
Runoff specifically & $7(8.14)$ \\
Fisheries & $6(7)$ \\
Sedimentation specifically & $5(5.8)$ \\
Human impacts generally & $4(4.7)$ \\
Tourism & $2(2.3)$ \\
Other: Trampling, invasive species, storms, increases in & $11(12.7)$ \\
seed predators, mineral extraction, trampling, damage to & \\
sediments, plastics, land reclamation, and aquaculture & \\
\hline
\end{tabular}

partnerships with public and private organisations, businesses, clubs and societies. This could include working with Scout Groups and Youth Clubs to undertake field sampling activities. These methods would guarantee high levels of group organisation and guaranteed numbers associated with such activities, as well as the ability to direct their participation more readily. Additionally, targeting groups which are already associated with the marine environment (e.g., water sports enthusiasts) may pose fruitful due to an existing social connection with the sea and a potentially enhanced drive to protect it.

Given the researcher-heavy demographic of seagrass CS users here, it is evident that a regime shift is needed to diversify the current user base of these projects to better promote community inclusivity if seagrass CS projects are to be able to collect Big Data. At present, although users report altruistic and environmentally positive motivations, limited deterrence, and positivity towards methods currently utilised (e.g., mobile phones), seagrass CS projects are not benefiting from increased inclusivity. Increased inclusivity, possibly as a result of improved outreach and engagement beyond the current demographic, is essential if we are to adequately conserve these important ecosystems into the future.

Continued effort is needed to increase public awareness of and exposure to seagrass ecosystems as a method of promoting enhanced environmental stewardship and to help combat the more general current trend of disconnection between humans and their local environment (Schuttler et al., 2018). Although this study focuses on a highly specific set of marine CS projects, findings here are applicable to other marine CS programmes where recruitment tends to lag terrestrial counterparts more broadly. Alignment between participant responses here and

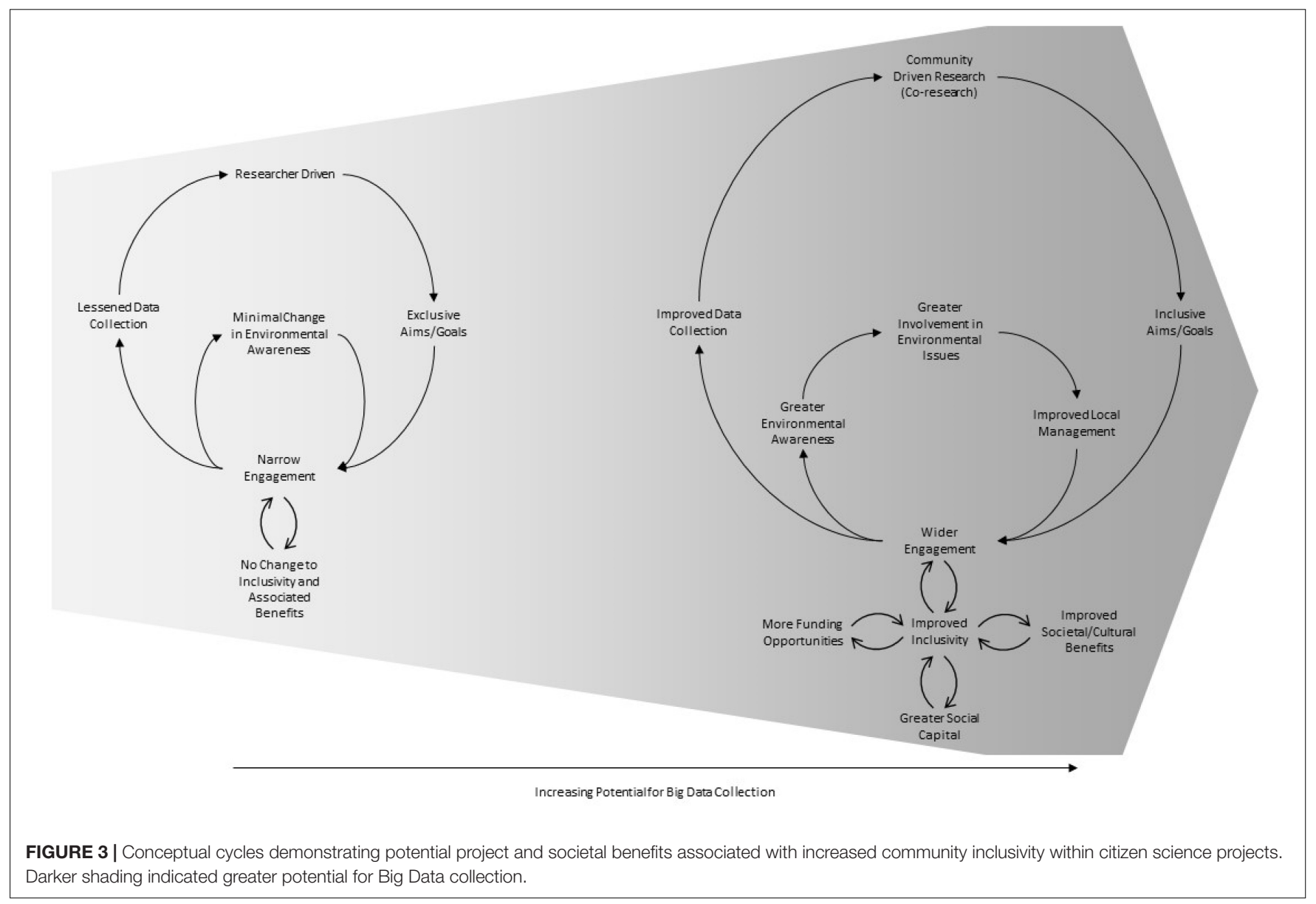


existing environmental CS literature suggests that salient themes are present universally across environmental CS projects and that integrating these themes into recruitment efforts may promote better success. Given the variation in media types used by respondents here (Table 2), dissemination of recruitment information should be completed with a variety of media types (e.g., email, websites, in person events, flyers, etc.). Further, to encourage broader participation, recruitment efforts should stress the potential for knowledge transfer, novel social interactions, and stewardship of local environments as these concepts were primary drivers of participation in our study and in the wider literature. By targeting these drivers during recruitment, the creation of a larger and more motivated user base may be tangible.

\section{DATA AVAILABILITY STATEMENT}

The original contributions presented in the study are included in the article/Supplementary Material, further inquiries can be directed to the corresponding author/s.

\section{ETHICS STATEMENT}

The studies involving human participants were reviewed and approved by University of York Environment Department Ethics

\section{REFERENCES}

Agbo, A. A. (2010). Cronbach's alpha: review of limitations and associated recommendations. J. Psychol. Afr. 20, 233-239. doi: 10.1080/14330237.2010. 10820371

Andrews, D., Nonnecke, B., and Preece, J. (2003). Conducting research on the internet: online survey design, development and implementation guidelines. Int. J. Hum. Comput. Interact. 16, 185-210. doi: 10.1207/S15327590IJHC 1602_04

August, T., Harvey, M., Lightfoot, P., Kilbey, D., Papadopoulos, T., and Jepson, P. (2015). Emerging technologies for biological recording. Biol. J. Linn. Soc. 115, 731-749. doi: 10.1111/bij.12534

Barbier, E. B., Hacker, S. D., Kennedy, C., Kock, E. W., Stier, A. C., and Sillman, B. R. (2011). The value of estuarine and coastal ecosystem services. Ecol. Monogr. 81, 169-193. doi: 10.1890/10-1510.1

Bela, G., Peltola, T., Young, J. C., Arpin, I., Pataki, G., Hauck, J., et al. (2016). Learning and the transformative potential of citizen science. Conserv. Biol. 30, 990-999. doi: 10.1111/cobi.12762

Bradshaw, B. (2003). Questioning the credibility and capacity of community-based resource management. Can. Geogr. 47, 137-150. doi: 10.1111/1541-0064.t011-00001

Brammer, J. R., Brunet, N. D., Burton, A. C., Cuerrier, A., Danielsen, F., Dewan, K., et al. (2016). The role of digital data entry in participatory environmental monitoring. Conserv. Biol. 30, 1277-1287. doi: 10.1111/cobi.12727

Bruyere, B., and Rappe, S. (2007). Identifying the motivations of environmental volunteers. J. Environ. Plann. Manag. 50, 503-516. doi: 10.1080/09640560701402034

Carifio, J., and Perla, R. (2008). Resolving the 50-year debate around using and misusing Likert scales. Med. Educ. 42, 1150-1152. doi: 10.1111/j.1365-2923. 2008.03172.x

Cigliano, J. A., Meyer, R., Ballard, H. L., Freitag, A., Phillips, T. B., and Wasser, A. (2015). Making marine and coastal citizen science matter. Ocean Coastal Manag. 115, 77-87. doi: 10.1016/j.ocecoaman.2015. 06.012
Committee. The patients/participants provided their written informed consent to participate in this study.

\section{AUTHOR CONTRIBUTIONS}

OD and IS contributed via questionnaire creation, dissemination, and data analysis. LC-U supervised all aspects and helped conceive the initial idea. RU, BJ, and LM helped to conceive the initial idea and helped seat the manuscript in a broader context. All authors contributed to discussions and aided in the final manuscript preparation.

\section{ACKNOWLEDGMENTS}

The authors would like to thank Seagrass-Watch, Murdoch University Seagrass Email Forum and the United Kingdom Seagrass Network for participation in the study and facilitating access to potential study participants.

\section{SUPPLEMENTARY MATERIAL}

The Supplementary Material for this article can be found online at: https://www.frontiersin.org/articles/10.3389/fmars. 2021.610397/full\#supplementary-material

Conrad, C. C., and Hilchey, K. G. (2011). A review of citizen science and community-based environmental monitoring: issues and opportunities. Environ. Monit. Assess 176, 273-291. doi: 10.1007/s10661-010-1582-5

Conrad, C. T., and Daoust, T. (2008). Community-based monitoring frameworks: increasing the effectiveness of environmental stewardship. Environ. Manage. 41, 358-366. doi: 10.1007/s00267-007-9042-x

Costello, A. B., and Osborne, J. W. (2005). Best practices in exploratory factor analysis: four recommendations for getting the most from your analysis. Pract. Assess. Res. Educ. 10, 1-9.

Crawley, M. J. (2013). The R Book. Chichester: John Wiley and Sons.

Cronbach, L. J. (1951). Coefficient alpha and the internal structure of tests. Psychometrika 16, 297-334. doi: 10.1007/BF02310555

Danielsen, F., Pirhofer-Walzl, K., Adrian, T. P., Kapijimpanga, D. R., Burgess, N. D., Jensen, P. M., et al. (2014). Linking public participation in scientific research to the indicators and needs of international environmental agreements. Conserv. Lett. 7, 12-24. doi: 10.1111/conl.12024

Diaz, S., Fargione, J., Chapin, F. S. III, and Tilman, D. (2006). Biodiversity loss threatens human well-being. PLoS Biol. 4:e277. doi: 10.1371/journal.pbio. 0040277

Drew, J. A. (2005). Use of traditional ecological knowledge in marine conservation. Conserv. Biol. 19, 1286-1293. doi: 10.1111/j.1523-1739.2005.00158.x

Driscoll, D. A., Bland, L. M., Bryan, B. A., Newsome, T. M., Nicholson, E., Ritchie, E. G., et al. (2018). A biodiversity-crisis hierarchy to evaluate and refine conservation indicators. Nat. Ecol. Evol. 2, 775-781. doi: 10.1038/s41559-0180504-8

Duffy, J. E., Benedetti-Cecchi, L., Trinanes, J., Muller-Karger, F. E., Ambo-Rappe, R., Boström, C., et al. (2019). Toward a coordinated global observing system for seagrasses and marine macroalgae. Front. Mar. Sci. 6:317. doi: 10.3389/fmars. 2019.00317

Ellwood, E. R., Crimmins, T. M., and Miller-Rushing, A. J. (2017). Citizen science and conservation: recommendations for a rapidly moving field. Biol. Conserv. 208, 1-4. doi: 10.1016/j.biocon.2016.10.014

Elo, S., and Kyngäs, H. (2008). The qualitative content analysis process. J. Adv. Nurs. 62, 107-115. doi: 10.1111/j.1365-2648.2007.04569.x 
Etikan, I. (2016). Comparison of convenience sampling and purposive sampling. Am. J. Theoretical Appl. Stat. 5, 1-2016. doi: 10.11648/j.ajtas.20160501.11

Franzoni, C., and Sauermann, H. (2014). Crowd science: the organization of scientific research in open collaborative projects. Res. Policy 43, 1-20. doi: 10.1016/j.respol.2013.07.005

Friedman, W. R., Halpern, B. S., McLeod, E., Beck, M. W., Duarte, C. M., Kappel, C. V., et al. (2020). Research priorities for achieving healthy marine ecosystems and human communities in a changing climate. Front. Mar. Sci. 7:5. doi: 10. 3389/fmars.2020.00005

Geoghegan, H., Dyke, A., Pateman, R., West, S., and Everett, G. (2016). Understanding Motivations for Citizen Science. Final Report on behalf of the UK Environmental Observation Framework. (UKEOF), University of Reading, Stockholm Environment Institute. (University of York) and University of the West of England. Heslington: University of York, 1-124.

Halpern, B. S., Walbridge, S., Selkoe, K. A., Kappel, C. V., Micheli, F., Agrosa, C., et al. (2008). A Global Map of Human Impact on Marine Ecosystems. Science 319:948. doi: 10.1126/science.1149345

Hausmann, A., Slotow, R., Burns, J. K., and Di Minin, E. (2016). The ecosystem service of sense of place: Benefits for human well-being and biodiversity conservation. Environ. Conserv. 43, 117-127. doi: 10.1017/S0376892915000314

Haywood, B. K. (2014). A "Sense of place" in Public participation in scientific research. Sci. Educ. 98, 64-83. doi: 10.1002/sce.21087

Hind-Ozan, E. J., and Jones, B. L. (2018). Seagrass science is growing: a report on the 12th international seagrass biology workshop. Mar. Pollut. Bull. 134, 223-227. doi: 10.1016/j.marpolbul.2017.08.017

Hsieh, H. F., and Shannon, S. E. (2005). Three approaches to qualitative content analysis. Qual. Health Res. 15, 1277-1288. doi: 10.1177/1049732305276687

Hyder, K., Townhill, B., Anderson, L. G., Delany, J., and Pinnegar, J. K. (2015). Can citizen science contribute to the evidence-base that underpins marine policy? Mar. Policy 59, 112-120. doi: 10.1016/j.marpol.2015.04.022

Jones, B. L., Unsworth, R. K. F., McKenzie, L. J., Yoshida, R. L., and CullenUnsworth, L. C. (2018). Crowdsourcing conservation: The role of citizen science in securing a future for seagrass. Mar. Pollut. Bull. 134, 210-215. doi: 10.1016/j.marpolbul.2017.11.005

Jordan, R. C., Ballard, H. L., and Phillips, T. B. (2012). Key issues and new approaches for evaluating citizen-science learning outcomes. Front. Ecol. Environ. 10:307-309. doi: 10.1890/110280

Jordan, R. C., Gray, S. A., Howe, D. V., Brooks, W. R., and Ehrenfeld, J. G. (2011). Knowledge gain and behavioral change in citizen-science programs. Conserv. Biol. 25, 1148-1154. doi: 10.1111/j.1523-1739.2011.01745.x

Keniger, L. E., Gaston, K. J., Irvine, K. N., and Fuller, R. A. (2013). What are the benefits of interacting with nature? Int. J. Environ. Res. Public Health 10, 913-935. doi: 10.3390/ijerph10030913

Kitchin, R., and McArdle, G. (2016). What makes big data, big data? Exploring the ontological characteristics of 26 datasets. Big Data Soc. 3:2053951716631130. doi: 10.1177/2053951716631130

Kobori, H., Dickinson, J. L., Washitani, I., Sakurai, R., Amano, T., Komatsu, N., et al. (2016). Citizen science: a new approach to advance ecology, education, and conservation. Ecol. Res. 31, 1-19. doi: 10.1007/s11284-015-1314-y

Kullenberg, C., and Kasperowski, D. (2016). What is citizen science?-A scientometric meta-analysis. PLoS One 11:e0147152. doi: 10.1371/journal.pone. 0147152

Lance, C. E., Butts, M. M., and Michels, L. C. (2006). What did they really say?. Organ. Res. Methods 9, 202-220. doi: 10.1177/1094428105284919

Liu, Y., Qiu, M., Liu, C., and Guo, Z. (2017). Big data challenges in ocean observation: a survey. Pers. Ubiquitous Comput. 21, 55-65. doi: 10.1007/ s00779-016-0980-2

Martin, V., Smith, L., Bowling, A., Christidis, L., Lloyd, D., and Pecl, G. (2016). Citizens as scientists: what influences public contributions to marine research?. Sci. Commun. 38, 495-522. doi: 10.1177/1075547016656191

Martin, V. Y., Christidis, L., Lloyd, D. J., and Pecl, G. T. (2016). Understanding drivers, barriers and information sources for public participation in marine citizen science. J. Sci. Commun. 15, 1-19. doi: 10.22323/2.15020202

McClure, E., Sievers, M., Brown, C., Buelow, C., Ditria, E., Hayes, M., et al. (2020). Artificial inteligence meets citizen science to supercharge ecological monitoring. Patterns 1:100109. doi: 10.1016/j.patter.2020.100109

McKenzie, L., Collier, C., Waycott, M., Unsworth, R. K. F., Yoshida, R., and Smith, N. (2012). "Monitoring inshore seagrasses of the GBR and responses to water quality," in Proceedings of the 12th International Coral Reef Symposium, Cairns, Australia, 9-13 July 2012. Mini-Symposium 15b-Seagrasses and Seagrass Ecosystems, eds D. Yellowlees and T. P. Hughes (Townsville: James Cook University), 1-5.

McKenzie, L., Lee Long, W. J., Coles, R., and Roder, C. A. (2000). Seagrass-watch: community based monitoring of seagrass resources. Biol. Mar. Mediterr. 7, 393-396.

McKenzie, L., Yoshida, R., Langlois, L., Rau, J., Weatherall, K., Bishop, F., et al. (2017). Long-Term Seagrass Monitoring in Roebuck Bay, Broome: Report on the First 10 Years. A report for the Broome Community Seagrass Monitoring Project, Environs Kimberley. Centre for Tropical Water \& Aquatic Ecosystem Research. (TropWATER) Report 17/35. Cairns: James Cook University, $1-44$.

McKenzie, L., Yoshida, R., West, F., Lindsay, M., Yaakub, S. M., Bendell, B., et al. (2018). "Seagrass-watch: two decades of participatory scientific monitoring and science-based education provides insight into global seagrass resource status," in Proceedings of the World Seagrass Conference 2018 \& International Seagrass Biology Workshop 13, 11-17 June 2018, (UTown: National University of Singapore).

McKenzie, L. J., Campbell, S. J., and Roder, C. A. (2001). SeagrassWatch: Manual for Mapping \& Monitoring Seagrass Resources by Community. (Citizen) Volunteers. Townsville: Northern Fisheries Centre, $1-100$.

McKenzie, L. J., Nordlund, L. M., Jones, B. L., Cullen-Unsworth, L. C., Roelfsema, C., and Unsworth, R. K. F. (2020). The global distribution of seagrass meadows. Environ. Res. Lett. 15, 1-13. doi: 10.1088/1748-9326/ab7d06

McKenzie, L. J., Yoshida, R. L., Aini, J. W., Andréfouet, S., Colin, P. L., CullenUnsworth, L. C., et al. (2021). Seagrass ecosystem contributions to people's quality of life in the Pacific Island Countries and Territories. Mar. Pollut. Bull. 167:112307. doi: 10.1016/j.marpolbul.2021.112307

Murray, J. (2013). Likert data: what to use, parametric or non-parametric? Int. J. Bus. Soc. Sci. 4, 258-264.

Newman, G., Graham, J., Crall, A., and Laituri, M. (2011). The art and science of multi-scale citizen science support. Ecol. Inf. 6, 217-227. doi: 10.1016/j.ecoinf. 2011.03.002

Pretty, J., and Smith, D. (2004). Social capital in biodiversity conservation and management. Conserv. Biol. 18, 631-638. doi: 10.1111/j.1523-1739.2004. 00126.x

Qualtrics (2018). Qualtrics Survey Design Software. Provo, UT: Qualtrics.

R Core Team (2013). R: A Language and Environment for Statistical Computing. Vienna: R Foundation for Statistical Computing.

Raymond, C. M., Fazey, I., Reed, M. S., Stringer, L. C., Robinson, G. M., and Evely, A. C. (2010). Integrating local and scientific knowledge for environmental management. J. Environ. Manage. 91, 1766-1777. doi: 10.1016/j.jenvman.2010. 03.023

Revelle, W. R. (Photographer) (2017). psych: Procedures for Personality and Psychological Research. Software.

Rotman, D., Hammock, J., Preece, J., Hansen, D., and Boston, C. (2014). "Motivations affecting initial and long-term participation in citizen science projects in three countries," in Proceedings of the iConference 2014 Proceedings, (London: ACM).

Saunders, M. I., Leon, J. X., Callaghan, D. P., Roelfsema, C. M., Hamylton, S., Brown, C. J., et al. (2014). Interdependency of tropical marine ecosystems in response to climate change. Nat. Clim. Change 4, 724-729. doi: 10.1038/ nclimate 2274

Schuttler, S. G., Sorensen, A. E., Jordan, R. C., Cooper, C., and Shwartz, A. (2018). Bridging the nature gap: can citizen science reverse the extinction of experience?. Front. Ecol. Environ. 16:405-411. doi: 10.1002/fee.1826

Schwartz, S. H., Cieciuch, J., Vecchione, M., Davidov, E., Fischer, R., Beierlein, C., et al. (2012). Refining the theory of basic individual values. J. Pers. Soc. Psychol. 103, 663-688. doi: 10.1037/a0029393

Short, F. T., Polidoro, B., Livingstone, S. R., Carpenter, K. E., Bandeira, S., Bujang, J. S., et al. (2011). Extinction risk assessment of the world's seagrass species. Biol. Conserv. 144, 1961-1971. doi: 10.1016/j.biocon.2011.04.010

Sullivan, G. M., and Artino, A. R. Jr. (2013). Analyzing and interpreting data from likert-type scales. J. Grad. Med. Educ. 5, 541-542. doi: 10.4300/JGME-5-4-18

Thiel, M., Penna-Díaz, M., Luna-Jorquera, G., Salas, S., Sellanes, J., and Stotz, W. (2014). Citizen scientists and marine research: volunteer participants, their 
contributions, and projection for the future. Oceanogr Mar. Biol. 52, 257-314. doi: 10.1201/b17143-6

Trizano-Hermosilla, I., and Alvarado, J. S. M. (2016). Best alternatives to Cronbach's alpha reliability in realistic conditions: congeneric and asymmetrical measurements. Front. Psychol. 7:769. doi: 10.3389/fpsyg.2016.00769

Unsworth, R. K. F., McKenzie, L. J., Collier, C. J., Cullen-Unsworth, L. C., Duarte, C. M., Eklof, J. S., et al. (2018). Global challenges for seagrass conservation. Ambio 48, 801-815. doi: 10.1007/s13280-018-1115-y

van Keulen, M., Nordlund, L. M., and Cullen-Unsworth, L. C. (2018). Towards recognition of seagrasses, and their sustainable management. Mar. Pollut. Bull. 134, 1-4. doi: 10.1016/j.marpolbul.2018.08.046

Van Selm, M., and Jankowski, N. W. (2006). Conducting online surveys. Qual. Quant. 40, 435-456. doi: 10.1007/s11135-005-8081-8

Waycott, M., Duarte, C. M., Carruthers, T. J., Orth, R. J., Dennison, W. C., Olyarnik, S., et al. (2009). Accelerating loss of seagrasses across the globe threatens coastal ecosystems. Proc. Natl. Acad. Sci. U.S.A. 106, 12377-12381. doi: 10.1073/pnas.0905620106
Wickham, H., and Chang, W. (2016). Package 'ggplot2': 1-185. doi: 10.1007/978-3319-24277-4

Worm, B., Barbier, E. B., Beaumont, N., Duffy, J. E., Folke, C., Halpern, B. S., et al. (2006). Impacts of biodiversity loss on ocean ecosystem services. Science 314 787-790. doi: 10.1126/science.1132294

Conflict of Interest: The authors declare that the research was conducted in the absence of any commercial or financial relationships that could be construed as a potential conflict of interest.

Copyright (C) 2021 Dalby, Sinha, Unsworth, McKenzie, Jones and Cullen-Unsworth. This is an open-access article distributed under the terms of the Creative Commons Attribution License (CC BY). The use, distribution or reproduction in other forums is permitted, provided the original author(s) and the copyright owner(s) are credited and that the original publication in this journal is cited, in accordance with accepted academic practice. No use, distribution or reproduction is permitted which does not comply with these terms. 